\title{
Evaluation of the Effects of Digitization in the Process of Accounting Operations in a Selected Manufacturing Company
}

\author{
Zuzana Stefanovova ${ }^{1, *}$, Hana Bartkova ${ }^{2}$, and Jindra Peterkova ${ }^{3}$ \\ ${ }^{1}$ VŠB - Technical University of Ostrava, Faculty of Economics, Department of \\ Business Administration, Czech Republic \\ ${ }^{2}$ VŠB - Technical University of Ostrava, Faculty of Economics, Department of Accounting \\ and Taxes, Czech Republic \\ ${ }^{3}$ VŠB - Technical University of Ostrava, Faculty of Economics, Department of Business \\ Administration, Czech Republic
}

\begin{abstract}
The principles of industry 4.0 progressively penetrate into accounting. The process of accounting activities from entering accounting documents to posting accounting documents is now fully automated. Through digitization and artificial intelligence, the invoice is automatically read and recorded in the accounts. On the other hand, activities in the process of control of realized accounting operations, including financial management of the company, remain to the accountants. Digitization of invoices is based on converting from paper form by using document scanners to digital form. This is followed by automatic reading from invoices through AI which uses neural networks. Accounting Act is intended to define methods of using electronic documents, understanding accounting records. It will give the sufficient knowledge of the technology used and knowledge of employees to automate accounting operations. Despite this, digitization brings benefits in terms of time savings, lower costs, and an overview of the volume of liabilities on invoices. The aim of the paper is to evaluate the effects of digitization of accounting operations through corporate economic data. At the same time identify the main problems that arise during digitization. Case study will document the findings. The business data of a particular company and data from the Czech Statistical Office will be used for processing.
\end{abstract}




\section{Introduction}

Nowadays, digitization penetrates into all business activities, namely into the accounting. Analog data carrier are reformatted through the technology to digital form. European Commission harmonizes legislation and formats of digitization in the accounting. The impact of Directive 2014/55/EU, which obliges to all member states to implement einvoicing in public procurement processes by 2020. It applies at the request of the European Commission to create European standards for electronic invoicing. [1,2]

Digitization is changing the nature of accounting and it is associated with a positive and negative impacts on the business. On one hand, digitization provides easy and fast access to information. Documents can be shared on closed and open internet portals or shared disks as well as public storages that could provide access to all or limited number of users. On the other hand, to convert analogue documents into digital form is time consuming and we can consider that as one of the disadvantages of the digitization of documents. At the same time, it is expensive to provide new electronic data storage. The great progress in computer technology also means that previously digitized documents are stored in the forms, which today 's technology can no longer read. So that's why these old electronic versions of documents have to be transformed into new modern forms. [3,4]

The aim of the paper is to evaluate the effects of digitization of accounting operations focused on the purchasing process. To evaluate the effects of digitization, the paper uses a case study of a particular business and statistical data from 2018. Based on the findings from the case study and statistical data, the main problems which occurred within digitization have been identified.

\subsection{Basic Processing Methods}

The basic methods that were used in the paper include: empirical research, which consisted of obtaining field data and their analysis in in the surveyed enterprise. Another method used was analysis and synthesis, which characterized data from the selected company with a focus on material demand, processing of purchase and introduction of prices into the system, which has enabled a process leading to concrete knowledge and outputs. The deduction method was used to draw conclusions, which characterizes the exact sequence of steps in the application on the main problems that arise during digitization. Because of loyalty to the selected company, it will not be mentioned in the contribution. The obtained results are processed in a case study.

\subsection{Computer Technology and Robotic Process Automation (RPA)}

The use of computer technology represents a huge leap in the development of accounting forms and techniques, as it allows the processing of large volumes of data in a short time, a great flexibility in the output form of accounting information and capability of fast data transfer. [5, 6] Robotic process automation increased productivity for $95 \%$ of companies worldwide (74\% in the Czech Republic) - those data are mentioned in the survey from audit firm Deloitte (The robots are waiting). [7] 530 top managers of companies from around the world, including the Czech Republic, participated in this survey. According to the findings of this study, the fragmentation of processes, the lack of a clear RPA vision and the insufficient IT readiness are the main obstacles to the greater expansion of automation in companies.

The processing of received invoices is a key process as they open up opportunities for saving resources, gaining insight, and speeding processing. However, a large number of companies perceive inefficiencies in processing received invoices, especially in their manual acquisition and submission for approval. A common problem for companies is that 
a substantial proportion of invoices are still received on paper (40\%). Loss of invoices, high number of invoice discrepancies, slow approvals and even duplicate payments - these are other subsequent issues associated with this process. [8,9,10,11]

Businesses are introducing e-commerce, which is purchase or sell (ordering or receiving orders) over the Internet or a computer network (e. g. a closed inter-company network). It is crucial that the order is made (received or sent) electronically. The decisive factor is not the method of payment or the method of delivery. E-commerce can take place online on websites or on mobile applications. The order is filled in and sent via the e-shop, emarketplace, mobile applications or extranet. The second way of e-commerce is through electronic data exchange (EDI commerce), in which business documents (e. g. electronic orders) are exchanged between e-commerce partners. [12, 13, 14]

Companies are also developing company information systems as part of their digitization. These are applications that support agendas and processes in the areas of financial management, human resources, production, warehouse management, operation and costumer search and supply chain search. The most common systems are ERP, CRM, SCM, accounting programs and others. [15-19]

\section{Evaluation of digitization in the purchasing process}

The basic methods that were used in the paper include: empirical research, which consisted of obtaining field data and their analysis in in the surveyed enterprise. Another method used was analysis and synthesis, which characterized data from the selected company with a focus on material demand, processing of purchase and introduction of prices into the system, which has enabled a process leading to concrete knowledge and outputs. The deduction method was used to draw conclusions, which characterizes the exact sequence of steps in the application on the main problems that arise during digitization. Because of loyalty to the selected company, it will not be mentioned in the contribution. The obtained results are processed in a case study.

\subsection{Evaluation of Data from the Czech Statistical Office (CZSO)}

The CZSO implements an annual survey on the use of information and communication technologies in the business sector in the Czech Republic. This survey has been carried out in the Czech Republic since 2003 and is fully comparable with similar surveys conducted in other EU Member States. [20]

According to CZSO ' $\mathrm{s}$ data, there is an increase of companies which purchase electronically. There is a significant increase of the value of purchases made using electronic orders. Businesses prefer buying online via e-commerce over electronic data exchange.

Online shopping is mainly done by large companies (79\%), followed by small and medium-sized businesses (79\%). From the sectoral point of view, e-shopping is most used in the CZ-NACE $\mathbf{J}$ sector of information and communication.

Businesses have a long-term preference over electronic data exchange for e-shopping. In 2017 , telecom companies (90\%) made the most electronic order via the websites. Of the industries, e-shopping via websites is most used by companies involved in the production of computers and other electronic devices (75\%).

The highest intensity of e-shopping through electronic data exchange is observed in manufacturing industry in the production of computers and other electronic devices and equipment (64\%), following in telecommunications (58\%). 


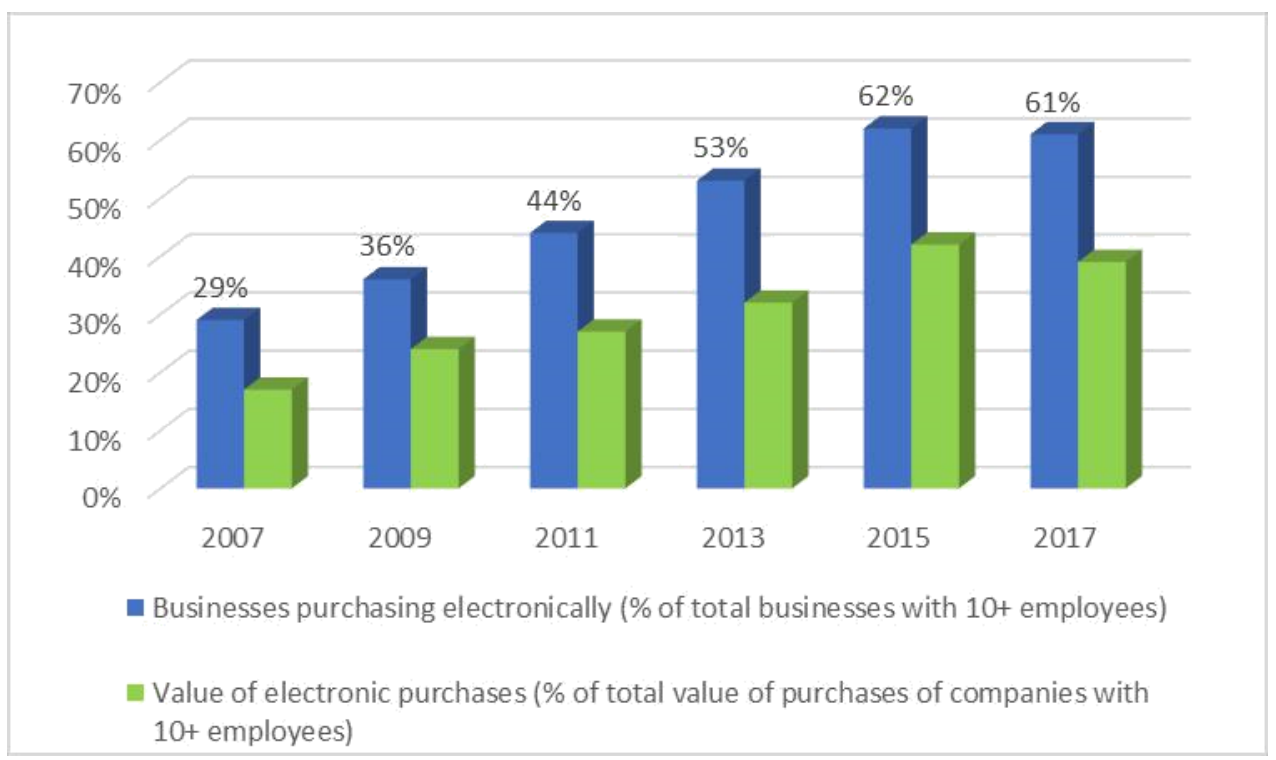

Fig 1. Electronic Shopping of Companies in the Czech Republic

(Mana, 2017)

\subsection{Case Study}

The case study describes the process of digitizing the purchase processing, material demand, including the introduction of prices into the system after restructuring and process optimization. For evaluation of digitization in the purchasing process, we focused on a transnational company that has a parent company in Germany. It is a family-owned German company, founded in 1937, with subsidiaries in the Czech Republic, Austria, Switzerland and the USA. It is currently one of the world's leading suppliers of logistics and storage systems. The company is mainly engaged in the production of large logistics units on a turnkey basis. It is a general supplier of logistics and distribution centres for large multinational chains such as IKEA or Jysk. The range of products includes highly dynamic warehousing and logistics systems, modern equipment for assembling shops, business premises and offices, waste and recycling products. The company is a general supplier of the aforementioned equipment. The company supplies to the customer its own technology and also the solution for the customer 's logistic flows. The research was carried out in a production plant - a subsidiary in the Czech Republic, which was founded in 1996. It is a limited liability company. In the Czech Republic is responsible for the production of technological components, it deals with the production of automated logistics systems (crates, stackers, conveyors) and static systems (racks, steel structures). The company in the Czech Republic underwent very dynamic development in the last twenty years. From the original producer of welded and varnished parts with 100 employees to a complex producer of complicated logistic units. Today we can find the latest engineering and manufacturing technologies and its know-how nowadays is the production and testing of logistics equipment, including their assembly on construction sites around the world. 


\subsection{Description of Processing the Purchase in a Selected Company}

On the basis of our own research, it was discovered that the orders are received electronically via the order interface, where they are afterwards processed by the sales department. In the same way are delivered the technical documentation (e. g. bill of materials (BOM) used for production). These are forwarded from sales department to the project managers, whose are responsible for the production of particular products. They check the deadlines and pricing and proceed the documentation for further processing.

The engineers create production BOMs, check the parts' manufacturability for each part, determine the manufacturing procedures, including production time, define the parts purchased, determine the order date and release them to production. This release to production creates in the system purchasing requirements. Purchased items are divided into two groups (parts ordered for the warehouse and for the project). Parts for the warehouse are controlled by the minimum quantity adjusted in the specific warehouse. "Unterdeckungsprüfung" - The list of undersized items - we can find there the items that are scarce for physical need and also for the advised need in the system. Project parts have a minimum supply of zero and are generated in the list of undersized items.

The differentiation of the individual items is set in the system in "Artikelstammu" Item list". For items in Artikelstamm are set important parameters for purchase, such as warehouse, item type (purchased / manufactured), WBZ - item delivery time or minimum quantity.

The whole process is carried out in the company AMS program (Auftrag management system), which contains modules of supply/demand, calculations, requirements, items, orders, purchase overview, information about suppliers, etc.).

\subsection{Demand of Material and Introduction of Prices into the System}

Buyers send non-binding requests via e-mail to various companies. The reason is the price difference and delivery date. They send a table showing the material - number, name, material, drawing, price, delivery date of the offer and delivery date of the material. They also send a drawing or a material information that are not shown in the drawing with the request. Submitted offers and suppliers are then put into the system AMS.

Table 1. Description of the table.

\begin{tabular}{|c|c|c|c|c|c|c|c|}
\hline $\begin{array}{c}\text { Artikel- } \\
\text { Nr. }\end{array}$ & Bezeichnung & Werkstoff & Zeichnung & \multicolumn{4}{|c|}{ Preis/Price } \\
\hline $\begin{array}{c}\text { Item } \\
\text { No. }\end{array}$ & Name & Material & Drawing & $\begin{array}{c}\text { 1-2 } \\
\text { St/pcs }\end{array}$ & $\begin{array}{c}\mathbf{3 - 1 0} \\
\text { St/pcs }\end{array}$ & $\begin{array}{r}\text { 11-49 } \\
\text { St/pcs }\end{array}$ & $\begin{array}{c}\text { 50- } \\
\text { St/pcs }\end{array}$ \\
\hline $\begin{array}{c}\text { H11111 } \\
1\end{array}$ & Befestigungsklotz & ALMGSI0.5 & Z061443211 & & & & \\
\hline
\end{tabular}

\subsection{Introducing Offers and Prices into the System - New Product}

The supplier, type of goods or materials, prices and WBZ (Wieder Beschaffung Zeit) will be introduced into the system. It is a given date when the supplier is able to deliver the material or goods. The standard delivery time is 21 days. If everything is in order, the item will be released (unlocked), can be itemized into the BOMs and then purchased. 


\section{Effects of digitization}

The following advantages and disadvantages which emerged for the company from the results obtained by mapping the digitization of the purchasing process from the case study and based on statistical data from the CZSO.

Table 1. Positive and negative effects.

\begin{tabular}{|l|l|}
\hline Positive Effects & Negative Effects \\
\hline Automation of routine processes & Time required for documents to be converted \\
\hline Time savings & Conservatism \\
\hline Cost savings & Fast technological progress \\
\hline Teamwork & Insufficient legislation \\
\hline Information sharing & Ignorant human potential \\
\hline Simplicity in solving tasks & Duplicity \\
\hline
\end{tabular}

\section{Conclusion}

The reasons for the lack of interest or reluctance to digitize accounting documents are not that the accounting technicians themselves do not know them and do not want to use them. The problem is that the current accounting systems in the Czech Republic are not ready for digitization and automation. Work with the archive of the documents in the new systems is practically impossible.

The digitization of accounting documents directly offers their sharing with clients in a cloud storage, which is suitable for remote backup of documents. It is also a good solution from the perspective of electronic security. At the moment, there is no comprehensive accounting system in the Czech market that works fully in the cloud.

The Czech legislation does not significantly shift in this matter either. That means that the Czech legislation does not direct the accounting entities to archive certain documents in digital form (e. g. documents on transactions above a certain value). On the other hand, it imposes requirements on them to provide the so-called immutability of the electronic copy of documents and conformity with the original.

It follows that the massive change in the digitization of accounting practice will not be decided by any amendment or other European directive. Changes will be naturally proven by the practice of business economists who realize specific economic processes in a given place.

\section{References}

1. D. Nerudova, Danová politika v Evropske unii. (Wolters Kluwer, Prague, 2017).

2. T. Malmi, Managerialist studies in management accounting: 1990-2014. Management Accounting Research 31, (2016)

3. P. Casas-Arce, S. M. Lourenco, F. A. Martínez-Jerez, The Performance Effect of Feedback Frequency and Detail: Evidence from a Fild Experiment in Customer Satisfaction. Journal of Accounting Research 55, 5 (2017) 
4. J. Gazda et all., Tax optimization in anagent-based model of real-time spectrum secondary market. Telecommunication Systems 64, 3 (2017)

5. Collective of authors, Abeceda účetnictví pro podnikatele. (Anag, Olomouc, 2018)

6. Collective of authors, Meritum Účetnictví podnikatelů. (Anag, Olomouc 2018).

7. L. Müllerova, V. Kralicek. Auditing pro manažery aneb jak porozumét ověrování účetni závěrky statutárním auditorem. (Wolters Kluwer, Prague, 2018).

8. J. Skalova, Podvojné účetnictví. (Grada, Prague, 2018).

9. V. Vybíhal et all, Mzdové účetnictví, (Grada, Prague, 2018).

10. R. Eschenbach, Controlling. (Wolters Kluwer, Prague, 2004).

11. B. Král et all, Manažerské účetnictví. (Management Press, Prague, 2018).

12. J. Dvořáková, Finanční účetnictví a výkaznictví podle mezinárodních standardů IFRS. (Bizbooks, Brno, 2017).

13. J. Valach et all, Finanční ř́zení podniku. (Ekopress, Prague, 2009).

14. D. Kovanicová, Finanční účetnictví: světový koncept. (Polygon, Prague, 2004).

15. R. Eschenbach a H. Siller, Profesionální controlling - koncepce a nástroje. ( Wolters Kluwer, Prague, 2012).

16. E. M. Barth, Measurement in Financial Reporting: The Need for Concepts. Accounting Horrizonts 28, 2 (2014)

17. E. Kieso, E. Donald a J. J. Weygrant, Intermediate Accounting, (Wiley, Hoboken, 2013).

18. J. R. Graham, C. R. Harvey, S. Rajgopal. The economic implications of corporate financial reporting. Journal of Accounting and Economic 40, 1-3 (2005)

19. E. Cefis, O. Marsili, D. Rigamoti, In and Out of Balance: Industry Relatedness, Learning Capabilities and Post-Acquisition Innovative Performance. Journal of Management Studies, (2019)

20. M. Mana, Informační společnost v číslech, (ČSÚ, 2017). 